\title{
ОСОБЛИВОСТІ ЛІКУВАЛЬНО-ПРОФІЛАКТИЧНИХ ЗАХОДІВ У ДІТЕЙ РАННЬОГО ВІКУ, ЯКІ МАЮТЬ ПОРУШЕННЯ ФОСФОРНО-КАЛЬЦІЄВОГО ОБМІНУ
}

Вступ. Вітамін D відіграє ключову роль в обміні кальцію та фросфору і важливу роль у метаболізмі, тому є необхідним для розвитку дитини.

Мета дослідження - вивчити особливості фросфорно-кальцієвого гомеостазу та забезпечення вітаміном D у дітей раннього віку, народжених з великою масою тіла.

Методи дослідження. У дослідження було включено 82 дитини віком від 3 до 6 місяців та масою тіла при народженні понад 2500 г, гестаційний вік - 37 тижнів і більше. У разі виявлення порушення фросфрорно-кальцієвого гомеостазу і забезпечення 25-OH вітаміном $D_{3}\left(25(\mathrm{OH}) \mathrm{D}_{3}\right)$, з метою усунення головних симптомів захворювання з боку кісткової, нервової та інших систем організму дитини і нормалізації показників фосфорно-кальцієвого обміну в дітей, проводили корекцію препаратами вітаміну $D_{3}$ відповідно до протоколу Міністерства охорони здоров'я України від 10 січня 2005 р. № 9.

Результати й обговорення. 3 метою оцінки забезпечення 25(OH)D у уітей, хворих на вітамін D-де-

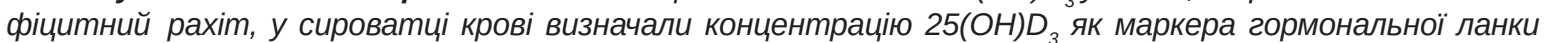
ремоделювання кісткової тканини. Між показником кальцію в сироватці крові після лікування та рівнем $25(\mathrm{OH}) D_{3}$ після лікування існував достовірний прямий помірний зв'язок $(R=0,560 ; p=0,0126)$ тільки у хлопчиків. Між показником лужної фоосфатази в сироватці крові після лікування та рівнем 25(OH)D після лікування відзначали достовірний зворотний сильний зв'язок ( $R=-0,555 ; p<0,001)$. Тобто при більшому вмісті лужної фроссратази після лікування спостерігали тенденцію до зменшення рівня 25(OH)D.

Висновки. Діти, народжені з великою масою тіла (понад 4000 2), мають дефіцит вітаміну $D_{3}$ порівняно з дітьми, народженими з нормальною масою тіла. Маса тіла при народженні й у момент обстеження корелює з рівнем вітаміну $D_{3} i \epsilon$ фрактором ризику дефріциту вітаміну $D_{3}$ (негативна кореляція). У результаті проведеної корекції недостатності вітаміну $D_{3} \in$ позитивна динаміка.

КЛЮчОВІ СЛОВА: діти, народжені з великою масою тіла; фосфорно-кальцієвий обмін; вітамін D; фоссрор; кальцій; лужна фоссратаза.

ВСТУП. Вітамін D - необхідний для організму людини субстрат, який відіграє ключову роль в обміні кальцію та фросфрору і важливу роль у метаболізмі, тому є необхідним для розвитку дитини $[1,2]$. У дитячій популяції десріцит цього вітаміну призводить до розвитку рахіту, остеомаляції, виникнення гіпокальціємічних судом [3-6].

Розширені та вдосконалені діагностичні можливості й результати багатьох досліджень, які проводять у світі, вказують на багатовекторну роль вітаміну D в організмі людини і різноманітні негативні наслідки, пов'язані з його недостатньою забезпеченістю, особливо серед дітей. Тому зросла увага до питань забезпеченості організму даним вітаміном у різні вікові періоди (с) Н. В. Камуть, 2018. життя людини, зокрема в дитячому віці. Збільшення об'єму наукових даних із цієї проблеми, що базується на принципах доказової медицини, спонукає практичних фрахівців до перегляду та актуалізації діючих стандартів діагностики, лікування та профрілактики захворювань, асоційованих із гіповітамінозом D [7-9].

На даний час дефріцит вітаміну D являє собою пандемію, що охоплює велику частину загальної популяції, включаючи дітей і підлітків, вагітних та матерів-годувальниць. За сучасними даними, вітамін D розглядають як гормон, що зумовлено його поліфункціональним впливом на організм людини [9-11].

Останнім часом, у зв'язку із зростанням частоти дефіциту вітаміну D серед європейської дитячої популяції, збільшилась зацікавленість 
даною проблемою з боку фахівців у галузі охорони здоров'я, засобів масової інформації та громадськості [12].

Особливе занепокоєння викликає недостатня забезпеченість цим вітаміном вагітних і матерів-годувальниць. Незважаючи на широке застосування полівітамінних комплексів, десріцит вітаміну D серед вагітних жінок часто реєструють у багатьох країнах світу, його частота становить від 18 до 98 \%. Значна поширеність низьких значень вітаміну D у матерів означає, що досить високий відсоток дітей в усьому світі народжується з недостатнім депо цього вітаміну $[2,5,12]$.

Десріцит вітаміну D $є$ головним, але не єдиним етіологічним фрактором у розвитку рахіту в дітей раннього віку. Підтвердження цього отримано завдяки можливості визначати концентрацію метаболітів вітаміну D у крові. Було з'ясовано, що не завжди в дітей із клінічними і біохімічними ознаками рахіту має місце низький рівень вітаміну D, підтверджений лабораторно [2, 3, 13]. Поряд 3 десріцитом вітаміну D у розвитку рахіту важливу роль відіграють недостатнє надходження в організм дитини кальцію, фросфору, магнію, білків, інших вітамінів (С, групи В) і мінералів, незрілість ендокринних систем, що здійснюють регуляцію процесів остеогенезу, транспортних механізмів та інших важливих обмінних реакцій $[8,9]$. Саме розуміння рахіту як поліетіологічного захворювання дозволяє організувати його адекватне лікування та профрілактику [2, 3, 13, 14].

Мета дослідження - вивчити особливості фоссрорно-кальцієвого гомеостазу та забезпечення вітаміном D у дітей раннього віку, народжених з великою масою тіла.

МЕТОДИ ДОСЛІДЖЕННЯ. У дослідження включено 82 дитини віком від 3 до 6 місяців, які перебували на лікуванні та спостереженні в міській дитячій лікарні м. Львова з приводу захворювань системи органів дихання. До критеріїв включення належали вік дітей від 3 до 6 місяців, маса тіла при народженні понад 2500 г, гестаційний вік 37 тижнів і більше. Діти, в яких визначали рівень вітаміну $D_{3}$, перебували в періоді реконвалесценції щодо захворювань системи органів дихання та шлунково-кишкового тракту. Критерієм виключення були уроджені вади розвитку органів та систем.

Усіх обстежуваних було поділено на 2 групи: основну $(n=41)$ - діти, народжені 3 масою тіла 4000 г і більше; контрольну ( $\mathrm{n}=41)$ - діти, народжені 3 масою тіла від 2500 до 3999 г. Аналізували фоссфорно-кальцієвий обмін, тобто визначали рівень фоссрору, кальцію та лужної фоосфратази в сироватці крові, а також рівень 25-ОН вітаміну $\mathrm{D}_{3}\left(25(\mathrm{OH}) \mathrm{D}_{3}\right)$ у сироватці крові дітей на початку і наприкінці дослідження.

У разі виявлення порушення фоссрорнокальцієвого гомеостазу і забезпечення $25(\mathrm{OH}) \mathrm{D}_{3}$, 3 метою усунення головних симптомів захворювання $з$ боку кісткової, нервової та інших систем організму дитини і нормалізації показників фоосфрорно-кальцієвого обміну в дітей, проводили корекцію препаратами вітаміну $\mathrm{D}_{3}$ відповідно до протоколу Міністерства охорони здоров'я України від 10 січня 2005 р. № 9. Визначали концентрацію вітаміну D у сироватці крові, проводячи ELISA. Статистичну обробку отриманих даних проводили з використанням програмного забезпечення LibreOffice v.5.2.2.2, InVivoStat v.3.0 (1), STATICTICA 10 та SofaStat v.1.4.6(2).

Оскільки окремі ознаки вибірки за своїми характеристиками відрізнялись від нормального розподілу, при проведенні кореляційного аналізу було застосовано ранговий коефріцієнт кореляції Спірмена (R), а для аналізу достовірності різниці між ознаками до і після дослідження ранговий W-критерій Вілкоксона для пов'язаних груп та U-критерій Манна - Уїтні для непов'язаних. Результати в такому випадку представлено у вигляді Ме (25 \%; $75 \%)$, де Ме - медіана, 25 \% - перший квартиль, $75 \%$-третій квартиль. щодо ознак, які мали характеристики нормального розподілу, використовували t-критерій Стьюдента для залежних груп, для незалежних груп дані представлено у форматі $\mathrm{M} \pm \delta$, де $\mathrm{M}-$ середнє відхилення, $\delta$ - стандартне квадратичне відхилення.

РЕЗУЛЬТАТИ Й ОБГОВОРЕННЯ. 3 МЕТОЮ вивчення особливостей фоссрорно-кальцієвого гомеостазу і забезпечення вітаміном D у дітей, народжених з великою масою тіла, в сироватці крові визначали концентрацію вітаміну D як маркера гормональної ланки ремоделювання кісткової тканини, рівні фросфору, кальцію та лужної фоосфратази.

Для оцінки статусу вітаміну D в організмі дитини на сьогодні науковці та клініцисти використовують класиффікацію, згідно з положеннями якої інтерпретацію результатів дослідження концентрації сироваткового гідроксивітаміну D проводять незалежно від віку дитини. На думку більшості міжнародних організацій, десріцит має місце тоді, коли вміст 25(ОН)D ${ }_{3}$ нижчий 20 нг/мл (тобто менший 50 нмоль/л), рівень $25(\mathrm{OH}) \mathrm{D}_{3}$ від 21 до 29 нг/мл (тобто 52-72 нмоль/л) можна розглядати як індикатор відносної недостатності вітаміну D, а рівень 30 нг/мл і вищий - як достатній (тобто близький до нормального).

При проведенні аналізу забезпечення $25(\mathrm{OH}) \mathrm{D}_{3}$ у дітей основної групи встановлено, 
що частота зниження його статусу зростала паралельно зі збільшенням значень маси тіла. Десріцит 25(OH)D реєстрували в більшості дітей, які народилися з великою масою тіла (22 обстежуваних - $(52,38 \pm 8,79) \%)$, що достовірно частіше, ніж у дітей, які народилися 3 нормальною масою тіла (8 осіб - $(19,05 \pm 8,15) \%, p<0,05$; OR=2,98, S=0,53, 95 \% Cl: 1,04-8,52).

Було проведено аналіз показників коефіцієнта кореляції між рівнем вітаміну $\mathrm{D}_{3}$ в сироватці крові та іншими фракторами до і після лікування. Оцінюючи дані щодо маси тіла при народженні та показників фросфорно-кальцієвого обміну в дітей, які народилися 3 великою масою тіла, ми виявили кореляційний зв'язок між такими ознаками до лікування (табл. 1).
Аналізуючи отримані дані, можна зробити висновок про наявність кореляційного зв'язку між такими ознаками після лікування (табл. 2).

У результаті проведення подальшого дослідження встановлено, що між показником кальцію в сироватці крові після лікування та рівнем $25(\mathrm{OH}) \mathrm{D}_{3}$ після лікування існував достовірний прямий помірний зв'язок ( $R=0,560 ; p=0,0126)$ тільки у хлопчиків (рис. 1). Тобто при більшому вмісті кальцію у хлопчиків спостерігали вищий рівень $25(\mathrm{OH}) \mathrm{D}_{3}$.

Наступним етапом нашого дослідження було вивчення взаємозалежності між показником лужної фросфратази в сироватці крові після лікування та рівнем 25(OH)D після лікування. Встановлено, що між ними існує достовірний зворот-

Таблиця 1 - Показники коефіцієнта кореляції між рівнем вітаміну $\mathrm{D}_{3}$ сироватці крові та іншими факторами до лікування

\begin{tabular}{|l|c|c|c|c|}
\hline \multicolumn{1}{|c|}{ Стать } & Фактор & Об'єм вибірки & Значення R & Значення $\mathrm{p}$ \\
\hline Усього & Вік & 82 & $-0,127$ & 0,2573 \\
\hline Дівчатка & Вік & 41 & $-0,158$ & 0,3252 \\
\hline Хлопчики & Вік & 41 & $-0,147$ & 0,3585 \\
\hline Усього & Маса тіла при народженні & 82 & $-0,503$ & $<0,0001$ \\
\hline Дівчатка & Маса тіла при народженні & 41 & $-0,409$ & 0,0079 \\
\hline Хлопчики & Маса тіла при народженні & 41 & $-0,611$ & $<0,0001$ \\
\hline Усього & Лужна фросратаза & 82 & $-0,752$ & $<0,0001$ \\
\hline Дівчатка & Лужна фросфратаза & 41 & $-0,826$ & $<0,0001$ \\
\hline Хлопчики & Лужна фросфратаза & 41 & $-0,678$ & $<0,0001$ \\
\hline Усього & Кальцій & 82 & 0,709 & $<0,0001$ \\
\hline Дівчатка & Кальцій & 41 & 0,752 & $<0,0001$ \\
\hline Хлопчики & Кальцій & 41 & 0,676 & $<0,0001$ \\
\hline Усього & Фосрор & 82 & 0,734 & $<0,0001$ \\
\hline Дівчатка & Фосрор & 41 & 0,734 & $<0,0001$ \\
\hline Хлопчики & Фоссрор & 41 & 0,725 & $<0,0001$ \\
\hline Усього & Маса тіла під час дослідження & 82 & $-0,495$ & $<0,0001$ \\
\hline Дівчатка & Маса тіла під час дослідження & 41 & $-0,428$ & 0,0053 \\
\hline Хлопчики & Маса тіла під час дослідження & 41 & $-0,613$ & $<0,0001$ \\
\hline
\end{tabular}

Таблиця 2 - Показники коефіцієнта кореляції між рівнем вітаміну $\mathrm{D}_{3}$ в сироватці крові та іншими факторами після лікування

\begin{tabular}{|l|c|c|c|c|}
\hline \multicolumn{1}{|c|}{ Стать } & Фактор & Об'єм вибірки & Значення R & Значення $\mathrm{p}$ \\
\hline Усього & Фоссрор & 37 & 0,143 & 0,397 \\
\hline Дівчатка & Фосфор & 18 & 0,141 & 0,5773 \\
\hline Хлопчики & Фосфор & 19 & 0,151 & 0,5372 \\
\hline Усього & Кальцій & 37 & 0,242 & 0,1493 \\
\hline Дівчатка & Кальцій & 18 & $-0,276$ & 0,2678 \\
\hline Хлопчики & Кальцій & 19 & 0,56 & 0,0126 \\
\hline Усього & Лужна фросфратаза & 37 & $-0,555$ & 0,0004 \\
\hline Дівчатка & Лужна фросратаза & 18 & $-0,556$ & 0,0166 \\
\hline Хлопчики & Лужна фросфратаза & 19 & $-0,57$ & 0,0109 \\
\hline Усього & Маса тіла під час дослідження & 37 & $-0,007$ & 0,9695 \\
\hline Дівчатка & Маса тіла під час дослідження & 18 & $-0,101$ & 0,6906 \\
\hline Хлопчики & Маса тіла під час дослідження & 19 & 0,074 & 0,7634 \\
\hline Усього & Маса тіла при народженні & 37 & 0,076 & 0,654 \\
\hline Дівчатка & Маса тіла при народженні & 18 & $-0,065$ & 0,7985 \\
\hline Хлопчики & Маса тіла при народженні & 19 & 0,159 & 0,5155 \\
\hline
\end{tabular}


ний сильний зв'язок $(\mathrm{R}=-0,555 ; \mathrm{p}<0,001)$. Тобто рівня $25(\mathrm{OH}) \mathrm{D}_{3}$ після лікування. При цьому не при більшому вмісті лужної фросфратази після виявлено суттєвої різниці між хлопчиками та лікування спостерігали тенденцію до зменшення дівчатками (рис. 2).

$R=0,560 ; p<0,05$

$95 \%$ довірчий інтервал

Хлопчики

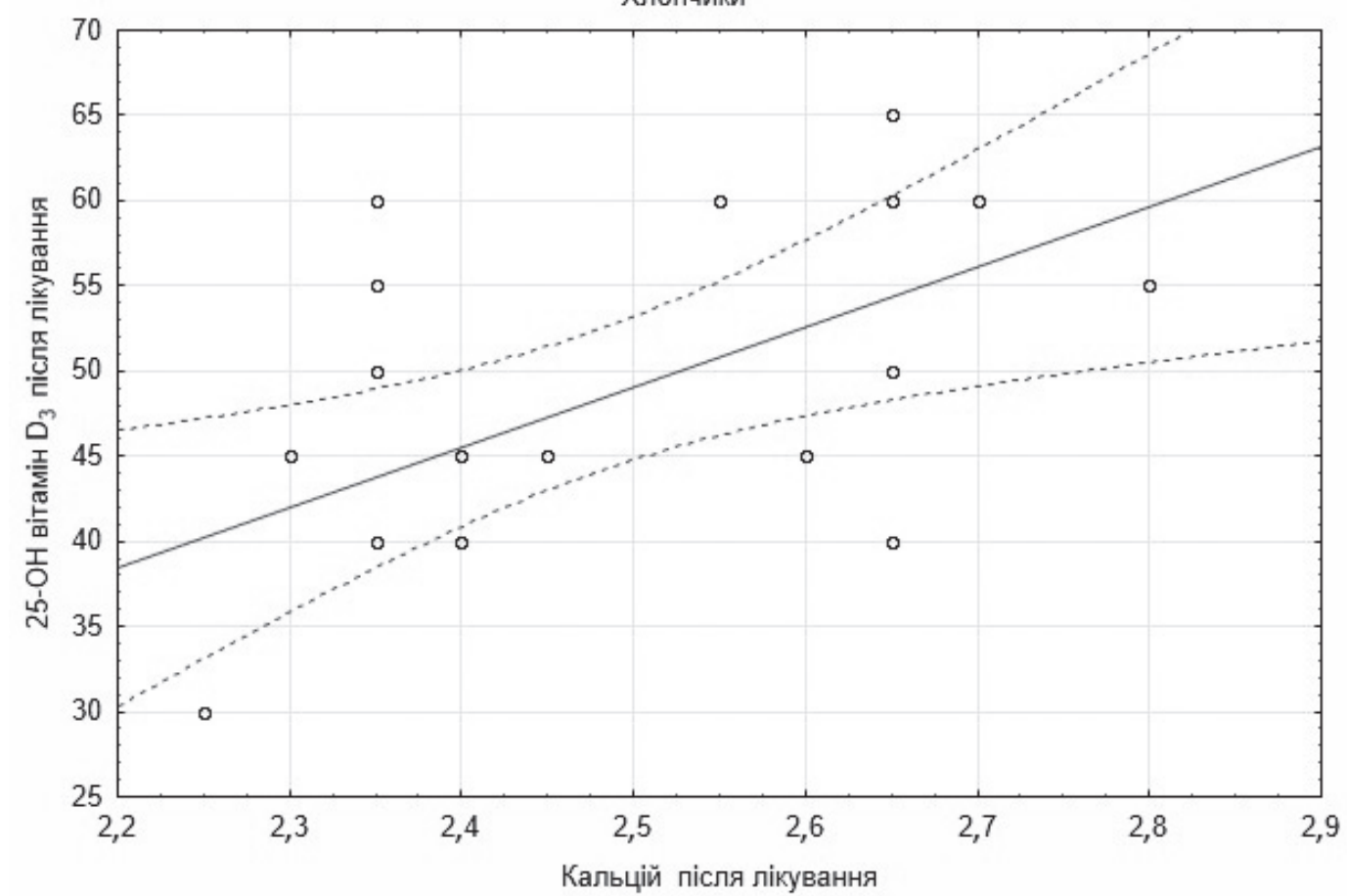

Рис. 1. Взаємозв'язок між показником 25-OH вітаміну $\mathrm{D}_{3}$ після лікування та рівнем кальцію після лікування у хлопчиків.

$R=-0,555 ; p<0,001$

$95 \%$ довірчий інтервал

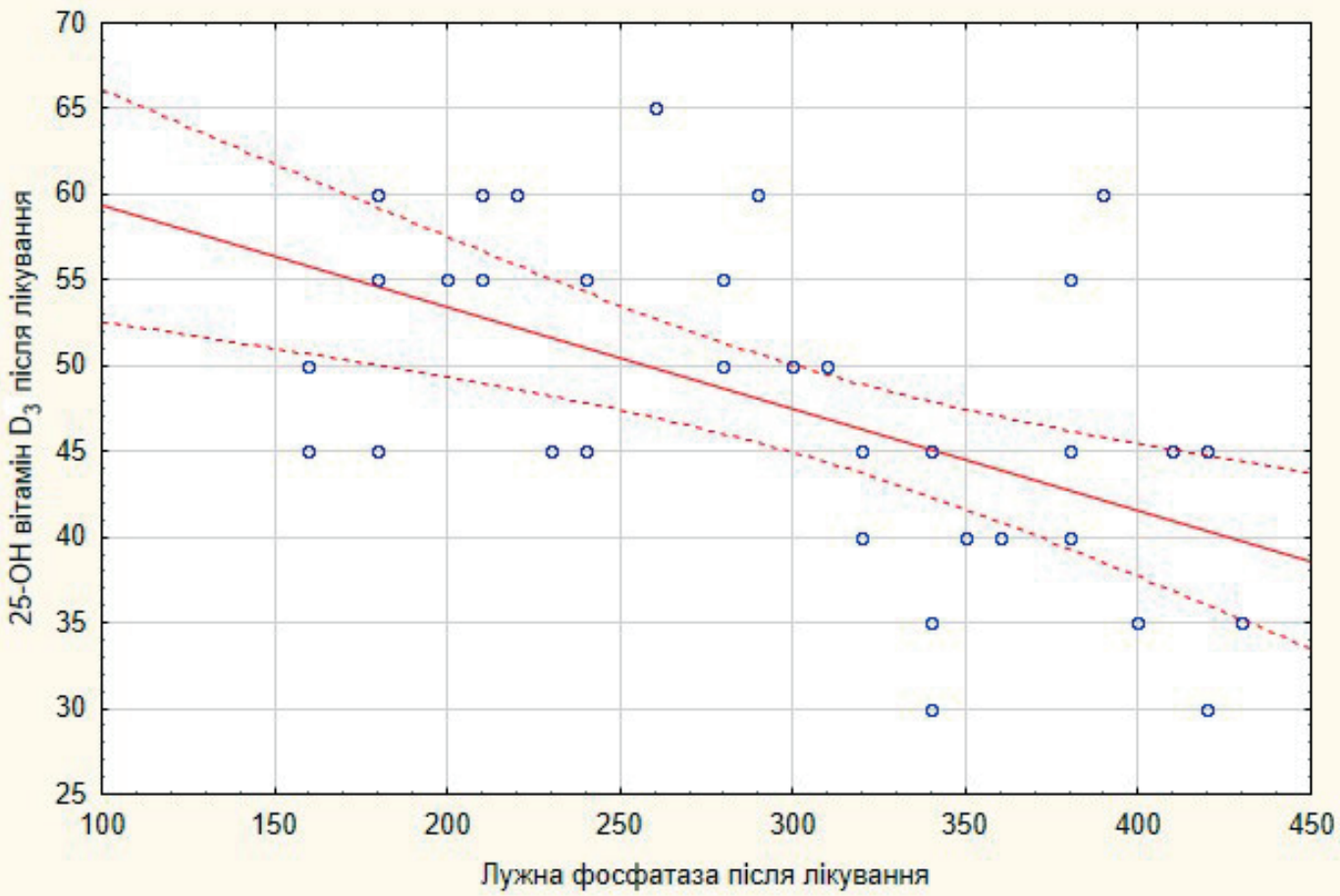

Рис. 2. Взаємозв'язок між показником 25-ОН вітаміну $\mathrm{D}_{3}$ після лікування та рівнем лужної фоссратази після лікування. 
ВИСНОВКИ. 1. Діти, народжені з великою масою тіла (понад 4000 г), мають десріцит вітаміну $\mathrm{D}_{3}$ порівняно з дітьми, народженими з нормальною масою тіла.
2. Маса при народженні й у момент обстеження корелює з рівнем вітаміну $\mathrm{D}_{3} \mathrm{i} \epsilon$ фрактором ризику десріциту вітаміну $D_{3}$ (негативна кореляція).

3. У результаті проведеної корекції недостатності вітаміну $\mathrm{D}_{3} \in$ позитивна динаміка.

\section{СПИСОК ЛІТЕРАТУРИ}

1. Winzenberg T. Effects of vitamin D supplementation on bone density in healthy children: systematic review and meta-analysis / T. Winzenberg, S. Powell, K. A. Shaw, G. Jones // BMJ. - 2011. - No. 342. - P. 7254

2. National Center for Health Statistics. Revised analytic note for NHANES 2000-2006 and NHANES III (1988-1994) 25-hydroxyvitamin D analysis. November 2010 [Electronic resource]. - Mode access: www.cdc. gov/nchs/data/nhanes/nhanes3/VitaminD_analyticnote. pdf. Accessed August 1, 2018/

3. The 2011 report on dietary reference intakes for calcium and vitamin D from the Institute of Medicine: what clinicians need to know / A. C. Ross, J. E. Manson, S. A. Abrams [et al.] // J. Clin. Endocrinol. Metab. 2011. - No. 96 (1). - P. 53

4. Bouillon R. Vitamin D: from photosynthesis, metabolism and action to clinical applications. In: Endocrinology, J. L. Jameson, L. J. De Groot (Eds.), Saunders Elsevier, Philadelphia, 2010. - 1089 p.

5 . The roles of vitamin $D$ in skeletal muscle: form, function, and metabolism / C. M. Girgis, R. J. Clifton-Bligh, M. W. Hamrick [et al.] // Endocr. Rev. - 2013. - No. 34. P. 33-34.

6. Vitamin $D(3)$ is more potent than vitamin $D(2)$ in humans / R. P. Heaney, R. R. Recker, J. Grote [et al.] // J. Clin. Endocrinol. Metab. - 2011. - No. 96 (3). - P. 447

7. Birth weight and fetal death in the United States: the effect of maternal diabetes during pregnancy / M. A. Mondestin, C. V. Ananth, J. C. Smulian, A. M. Vintzileos // Am. J. Obstet. Gynecol. -2002. - No. 187 (4). P. 922-926.

\section{REFERENCES}

1. Winzenberg, T., Powell, S., Shaw, K.A., \& Jones, G. (2011). Effects of vitamin D supplementation on bone density in healthy children: systematic review and meta-analysis. BMJ., 342, 7254

2. National Center for Health Statistics. Revised analytic note for NHANES 2000-2006 and NHANES III (1988-1994) 25-hydroxyvitamin D analysis. November 2010 [Electronic resource]. Retrieved from: www.cdc. gov/nchs/data/nhanes/nhanes3/VitaminD_analyticnote. pdf. Accessed August 1, 2018/

3. Ross, A.C., Manson, J.E., Abrams, S.A., \& Aloia, J.F. (2011). The 2011 report on dietary reference intakes for
8. Vitamin $D(3)$ is more potent than vitamin $D(2)$ in humans / R. P. Heaney, R. R. Recker, J. Grote [et al.] // J. Clin. Endocrinol. Metab. - 2011. - No. 96 (3). - P. 447.

9. The link between obesity and low circulating 25-hydroxyvitamin D concentrations: considerations and implications / C. P. Earthman, L. M. Beckman, K. Masodkar, S. D. Sibley // International Journal of Obesity. 2012. - 36, No. 3. - P. 387-396.

10. FGF-23 is a potent regulator of vitamin D metabolism and phosphate homeostasis / T. Shimada, H. Hasegawa, Y. Yamazaki [et al.] // J. Bone Miner. Res. 2014. - No. 19. - P. 429.

11. Holick M. F. The D-lemma: to screen or not to screen for 25-hydroxyvitamin D concentrations / M. F. Holick // Clin. Chem. - 2012. - 56 (5). - P. 729-731.

12. Vitamin $D$ in the healthy European paediatric population / C. Braegger, C. Campoy, V. Colomb [et al.]; ESPGHAN Committee on Nutrition // Journal of Pediatric Gastroenterology and Nutrition.- 2013. - 56, No. 6. P. 692-701.

13. Clinical review: The effect of vitamin $D$ on falls: a systematic review and meta-analysis / M. H. Murad, K. B. Elamin, N. O. Abu Elnour [et al.] // J. Clin. Endocrinol. Metab. - 2011. - No. 96. - P. 2997.

14. Ethnic differences in food sources of vitamin $D$ in adolescent American girls: the National Heart, Lung, and Blood Institute Growth and Health Study / L. V. Van Horn, R. Bausermann, S. Affenito [et al.] // Nutr. Res. 2011. - No. 31 (8). - P. 579-585.

calcium and vitamin D from the Institute of Medicine: what clinicians need to know. J. Clin. Endocrinol. Metab., 96 (1), 53

4. Bouillon, R., Jameson, J.L., \& De Groot, L.J. (2010). Vitamin D: from photosynthesis, metabolism and action to clinical applications. In: Endocrinology, Saunders Elsevier, Philadelphia.

5. Girgis, C.M., Clifton-Bligh, R.J., \& Hamrick, M.W. (2013). The roles of vitamin D in skeletal muscle: form, function, and metabolism. Endocr. Rev., 34, 33-34.

6. Heaney, R.P., Recker, R.R., Grote, J., Horst, R.L., \& Armas, L.A. (2011). Vitamin $D(3)$ is more potent than 
vitamin $\mathrm{D}(2)$ in humans. J. Clin. Endocrinol. Metab., 96 (3), 447

7. Mondestin, M.A., Ananth, C.V., Smulian, J.C., \& Vintzileos A.M. (2002). Birth weight and fetal death in the United States: the effect of maternal diabetes during pregnancy. Am. J. Obstet. Gynecol., 187 (4), 922-926.

8. Heaney, R.P., Heaney, R.P., Recker, R.R., Grote, J., Horst, R.L., \& Armas, L.A. (2011). Vitamin D(3) is more potent than vitamin $\mathrm{D}(2)$ in humans. J. Clin. Endocrinol. Metab., 96 (3), 447

9. Earthman, C.P., Beckman, L.M., Masodkar, K., \& Sibley, S.D. (2012). The link between obesity and low circulating 25-hydroxyvitamin D concentrations: considerations and implications. International Journal of Obesity, 36 (3), 387-396.

10. Shimada, T., Hasegawa, H., \& Yamazaki, Y. (2014). FGF-23 is a potent regulator of vitamin D metabolism and phosphate homeostasis. J. Bone Miner. Res., 19, 429.

11. Holick, M.F. (2012). The D-lemma: to screen or not to screen for 25-hydroxyvitamin $D$ concentrations. Clin. Chem., 56 (5), 729-731.

12. Braegger, C., Campoy, C., \& Colomb, V. (2013). Vitamin $D$ in the healthy European paediatric population. ESPGHAN Committee on Nutrition. Journal of Pediatric Gastroenterology and Nutrition, 56 (6), 692-701.

13. Murad, M.H., Elamin, K.B., \& Abu Elnour, N.O. (2011). Clinical review: The effect of vitamin D on falls: a systematic review and meta-analysis. J. Clin. Endocrinol. Metab., 96, 2997.

14. Van Horn, L.V., Bausermann, R., \& Affenito, S. (2011). Ethnic differences in food sources of vitamin D in adolescent American girls: the National Heart, Lung, and Blood Institute Growth and Health Study. Nutr. Res., 31 (8), 579-585.

\section{ОСОБЕННОСТИ ЛЕЧЕБНО-ПРОФИЛАКТИЧЕСКИХ МЕРОПРИЯТИЙ У ДЕТЕЙ РАННЕГО ВОЗРАСТА, ИМЕЮЩИХ НАРУШЕНИЯ ФОСФОРНО-КАЛЬЦИЕВОГО ОБМЕНА}

\section{Резюме}

Вступление. Витамин D играет ключевую роль в обмене кальция и фросфрора и важную роль в метаболизме, поэтому необходим для развития ребенка.

Цель исследования - изучить особенности фросфорно-кальциевого гомеостаза и обеспечения витамином D у детей раннего возраста, рожденных с большой массой тела.

Методы исследования. В исследование были включены 82 ребенка в возрасте от 3 до 6 месяцев и массой тела при рождении более 2500 г, гестационный возраст - 37 недель и больше. В случае выявления нарушения фоссфорно-кальциевого гомеостаза и обеспечения 25-OH витамином $D_{3}\left(25(\mathrm{OH}) \mathrm{D}_{3}\right)$, с целью устранения главных симптомов заболевания со стороны костной, нервной и других систем организма ребенка и нормализации показателей фросфрорно-кальциевого обмена у детей, проводили коррекцию препаратами витамина $D_{3}$ согласно протоколу Министерства здравоохранения Украины от 10 января 2005 ᄅ. № 9.

Результаты и обсуждение. С целью оценки обеспечения 25(OH) $D_{3}$ у детей, больных витамин $D$-де-

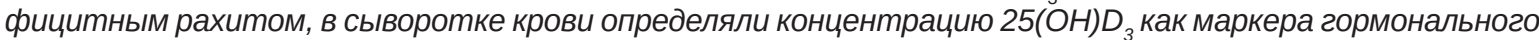
звена ремоделирования костной ткани. Между показателем кальция в сыворотке крови после лечения и уровнем $25(\mathrm{OH}) D_{3}$ после лечения существовала достоверная прямая умеренная связь $(R=0,560 ; p=0,0126)$ только у мальчиков. Между показателем щелочной фросфатазы в сыворотке крови после лечения и уровнем 25(OH)D $D_{3}$ после лечения отмечали достоверную обратную сильную связь $(R=-0,555 ; p<0,001)$. Tо есть при большем содержании щелочной фосфратазы после лечения наблюдали тенденцию к уменьшению уровня 25(OH) $D_{3}$.

Выводы. Дети, рожденные с большой массой тела (более 4000 г), имеют дефицит витамина $D_{3}$ по сравнению с детьми, рожденными с нормальной массой тела. Масса тела при рождении и в момент обследования коррелирует с уровнем витамина $D_{3}$ и является фрактором риска дефицита витамина $D_{3}$ (отрицательная корреляция). В результате проведенной коррекции недостаточности витамина $D_{3}$ ecmь положительная динамика.

КЛЮЧЕВЫЕ СЛОВА: дети, рожденные с большой массой тела; фосфрорно-кальциевый обмен; витамин D; фосорор; кальций; щелочная фосфратаза. 


\section{PECULIARITIES OF THERAPEUTIC AND PROPHYLACTIC MEASURES IN CHILDREN OF EARLY AGE WITH PHOSPHORUS AND CALCIUM METABOLISM DISORDERS}

\section{Summary}

Introduction. Vitamin $D$ is a substrate essential for the human body that plays a key role in the metabolism of calcium and phosphorus and accordingly is important for the development of a child.

The aim of the study - to research the peculiarities of phosphorous and calcium homeostasis and to supply the children of early age born with a high body mass with vitamin $D$.

Materials and Methods. The study included 82 children aged 3 to 6 months, with birth weight over $2.500 \mathrm{~g}$ and gestational age 37 weeks or more. When a disruption of phosphorous and calcium homeostasis and the lack of $25-\mathrm{OH}$ vitamin $\mathrm{D}_{3}$ was detected, in order to eliminate the main symptoms of a disease of the bone, nervous and other systems and normalization of phosphorous and calcium metabolism indicators, a correction was made with vitamin $D_{3}$ preparations according to protocol No. 9 of the Ministry of Health of Ukraine dated January 10, 2005.

Results and Discussion. In order to evaluate the availability of $25(\mathrm{OH}) \mathrm{D}_{3}$ in children with vitamin D deficiency rickets, $25(\mathrm{OH}) \mathrm{D}_{3}$ serum concentration was determined as a biochemical marker of bone remodeling. Between the indicators of calcium (serum) and the level of 25-OH vitamin $D_{3}$ after treatment there is a reliable, direct, moderate correlation $(R=0.560 ; p=0.0126)$ in boys only. Between the indicators of alkaline phosphatase (blood serum) and the level of $25-\mathrm{OH}$ vitamin $D_{3}$ after treatment, there is a reliable, reverse, strong relationship $(R=-0.555 ; p<0.001)$. That is, with a higher level of alkaline phosphatase after treatment, there is a tendency towards a decrease in the level of 25-OH vitamin D3.

Conclusions. Children born with a high body mass over $4.000 \mathrm{~g}$ have vitamin $D_{3}$ deficiency compared to children born with normal body mass. Weight at birth and at the time of examination correlate with the level of vitamin $D_{3}$ and is a risk factor of vitamin $D_{3}$ deficiency (negative correlation). Correction of vitamin $D_{3}$ deficiency results in positive dynamics.

KEY WORDS: children with high birth weight; phosphorus and calcium metabolism; vitamin D; phosphorus; calcium; alkaline phosphatase.

Адреса для листування: Н. В. Камуть, Львівський національний медичний університет імені Данила Галицького, вул. Пекарська, 69, Львів, 79010, Україна, e-mail: natalija.kamyt@gmail.com. 